\title{
Are the moth larvae able to withstand tree fall caused by wind storm?
}

\author{
M. Parák, J. Kulfan, P. Zach
}

\begin{abstract}
M. Parák, J. Kulfan, P. Zach 2014. Are the moth larvae able to withstand tree fall caused by wind storm?. Ann. For. Res. 58(1): 185-190.
\end{abstract}

Abstract. Wind storms play an important role in structuring European forests, however, the direct effects of strong wind on insects roosting in tree canopies are poorly known. In this study we assess the proportion of moth larvae which remain on Norway spruce (Picea abies [L.] Karst.) trees which have fallen during high winds. Next, we contribute to the knowledge of potential importance of such larvae in forests fragmented by local wind damage. We studied the effects of wind in spruce forest in the West Carpathians in March 2013. Branches were sampled from randomly chosen fallen and standing (undamaged) spruce trees in April 2013. Larvae or emerged moths were obtained from branches in the laboratory using photoeclectors. Assemblages of larvae were analysed at community level using several approaches. In total, 11 species of Lepidoptera were found on the branches, 10 of them overwinter as larvae and one as eggs. No differences were observed between abundance and species richness of larval assemblages on fallen and standing trees. Assemblages were very similar; there was no difference detected between standing and fallen trees. Overwintering larvae can successfully complete their development on wind-felled trees; hence, the emerged moths may contribute to greater infestation of standing spruce trees surviving wind disturbance. Keywords Norway spruce, moth larvae, wind storm, mountain forest, forest protection, Central Europe.

Authors. Michal Parák (parak@savzv.sk), Ján Kulfan, Peter Zach - Institute of Forest Ecology, Slovak Academy of Sciences, L. Štúra 2, 96053 Zvolen, Slovak Republic.

Manuscript received October 27, 2014; revised January 19, 2015; accepted February 27, 2015; online first March 18, 2015.

\section{Introduction}

Wind storms are important disturbance agents in forests (Zhu et al. 2004). Over the period $1950-2000$, they were responsible for more than half of the total damage of European forests and such damage seems to be increasing
(Schelhaas et al. 2003). Local wind storms are common (Schelhaas et al. 2003). They often cause forest fragmentation through the creation of mosaics of treefall gaps and undisturbed forest (Greenberg \& McNab 1998, Nagel et al. 2006).

Indirect effects of wind on forest insects due 
to changed habitat conditions have been frequently studied (e.g. Bouget \& Duelli 2004, Mitchell 2013). However, the immediate or short-term influence of strong wind on insects dwelling in tree canopies is only poorly understood. Wind of various intensities is common in Europe, e.g. average annual wind speed in the West Carpathians is $4-8 \mathrm{~m} \cdot \mathrm{s}^{-1}$. Tree-dwelling insects are adapted to such windy conditions using various strategies, e.g. endophagy or construction of silken tents and webs (e.g. Bradley et al. 1973, Schwenke 1978, Kulfan \& Patočka 1997). Free living insects usually cling on tightly to branches, twigs or leaves (Porter 1997). Hence, we suppose that the strong wind do not blow off most of insects from trees. However, some insects fall to the ground when roosting on broken off branches or dislodged by neighbouring moving twigs. Strong wind often snap or uproot trees whereby all animals inhabiting them undergo strong bump. Dislodgement of insects by shaking of host plants (branches, whole trees or herbaceous plants) is often used for insect sampling, such as beating or sweeping (Snodgrass 1993, Basset et al. 1997, Porter 1997, Leather 2005). Therefore, it is intuitive that dramatic movement such as experienced by falling trees during high winds could result in dislodgement of insects. However, some insects remain on fallen trees. For example, there were 13 moth species found on branches of Norway spruce (Picea abies [L.] Karst.) trees uprooted by a wind storm in late autumn (Kulfan \& Zach 2011). However, the proportion of insects remaining on fallen trees has not been systematically studied.

In this study, we assess the proportion of the moth larvae assemblage which withstands strong shaking of Norway spruce branches due to falling trees caused by wind storm. We also assess the potential importance of moth larvae remaining on fallen spruce trees in forests fragmented by local wind storm for forest protection.

\section{Materials and methods}

The study was conducted in a mature Norway spruce (Picea abies) forest of the High Tatras (West Carpathians, Slovakia; $49^{\circ} 08^{\prime} \mathrm{N}$, $19^{\circ} 54^{\prime} \mathrm{E}$; 950 - $1020 \mathrm{~m}$ a. s. 1.). No outbreak of herbivorous insect associates of spruce was observed during the growing period before sampling. On 15th March 2013 a wind storm (level 10 of a Beaufort wind scale) hit High Tatras, causing serious damage to spruce forests.

Moth larvae were sampled from 19 fallen (wind-felled) and 19 standing (not wind-felled trees in April 2013, about a month after the wind storm. Minimum distance between selected trees $(n=38)$ was $100 \mathrm{~m}$. Twenty terminal parts of branches $(0.5 \mathrm{~m}$ long each) were cut from lower part of crowns of each spruce individual. Sampled branches were stored in photoeclectors in the laboratory; and larvae or emerged moths were extracted and identified. We used the Wilcoxon rank sum test for two independent samples (Hollander et al. 2013) to compare moth larvae abundance and species richness between fallen and standing trees. Shannon index of diversity (H, using natural logarithm of a number) and Pielou index of evenness $(\mathrm{J})$ were computed for larvae assemblages on fallen and standing trees using pooled data. We used rarefaction curves (Oksanen 2011) to compare rarefied species richness between two samples (fallen respectively standing trees) and permutational multivariate analysis of variance (perMANOVA; Anderson 2001) to analyse dissimilarity matrix using linear model (McArdle \& Anderson 2001). Assemblages were compared using the Bray-Curtis dissimilarity index (Bray \& Curtis 1957, Faith et al. 1987). Samples with zero value were excluded from the analysis. $P$-values were computed based on 9,999 permutations from original data. Results of perMANOVA were graphically displayed using nonmetric multidimensional scaling (NMDS; Kruskal 1964). The close points in ordination graph 
show similar composition of assemblages. Reliability of ordination space is represented by Kruskal's stress value (Kruskal \& Wish 1978). The first axis represents the largest part of variability. Unit change in the axis represents half change in community composition (i.e. halfchange scaling; Oksanen 2013). All analyses were performed in R (RDC Team 2013) using the coin and vegan packages (Hothorn et al. 2013; Oksanen et al. 2013).

\section{Results}

A total of 203 individuals (97 and 106 on fallen or standing trees, respectively) and 11 species of spruce moth larvae were collected and identified. Ten recorded species overwinter as larvae; a single species [Zeiraphera griseana (Hübner 1799)] overwinters as eggs. With regard to species composition, assemblages overlapped between fallen trees ( 8 species) and standing trees (10 species), 7 species in common (Table 1). No differences were detected between abundance (Wilcoxon test, $Z=$ $-0.2204, P$-value $=0.8333$, Fig. 1a) and species richness of moth assemblages (Wilcoxon test, $Z=-0.1781, P$-value $=0.8657$, Fig. $1 b)$ on fallen and standing trees.

The rarefaction analysis, also, showed no difference in species richness between moth larvae assemblages on fallen and standing trees (Fig. 2a). Possible difference was evaluated in the highest comparable sample size, that is, 61 specimens. Species richness of moths was marginally lower on fallen trees (mean $=7.8, \mathrm{sd}=$ \pm 0.42 ) than on standing ones (mean $=9.06$, sd $= \pm 0.75$ ).

Moth larvae assemblages were very similar, showing no difference between standing and fallen trees at community level (perMANOVA, pseudo- $F=1.3899, P$-value $=0.2297$, partial $\left.R^{2}=0.04\right)$. The NMDS ordination of moth assemblages showed random trend between fallen and standing trees (Fig. 2b); and reliability and validity of points configuration was relatively high $($ stress $=15.5 \%)$.

\section{Discussion and conclusions}

Dropping off is frequent response of moth larvae and other insects to sudden shaking of host plants. It could be caused, for example, by natural enemies (predators, parasitoids) (Wilson \& Barclay 2006, Greeney et al. 2012)

Table 1 Dominance (\%) of moth larvae taxa

\begin{tabular}{llcc}
\hline Guild & Species & Fallen trees & Standing trees \\
\hline $\mathrm{Li}$ & Psychidae sp. & 4.10 & 4.70 \\
$\mathrm{Bu}$ & Argyresthia sp. & 10.30 & 7.60 \\
$\mathrm{Ns}$ & Batrachedra pinicolella (Zeller 1839) & 21.60 & 6.60 \\
$\mathrm{Ns}$ & Chionodes electella (Zeller 1839) & 15.50 & 14.20 \\
$\mathrm{Ns}$ & Archips oporana (Linnaeus 1758) & & 0.90 \\
$\mathrm{Ns}$ & Dichelia histrionana (Frölich 1828) & & 2.80 \\
$\mathrm{Ns}$ & Pseudohermenias abietana (Fabricius 1787) & 26.80 & 34.90 \\
$\mathrm{Ns}$ & Epinotia nanana (Treitschke 1835) & 16.50 & 18.90 \\
$\mathrm{Ep}$ & Cydia sp. & 3.10 & \\
$\mathrm{Ns}$ & Zeiraphera griseana (Hübner 1799) & & 0.90 \\
$\mathrm{Fl}$ & Thera variata (Denis \& Schiffermüller 1775) & 2.10 & 8.50 \\
& $H$ & 1.72 & 1.77 \\
& J & 0.83 & 0.77 \\
\hline
\end{tabular}

Note. Abbreviations: $H$ - Shannon index of diversity, $J$ - Pielou index of evenness, Larval guilds: Li - species feeding on lichens or algae, $\mathrm{Bu}$ - bud-borers, Ns - needle-spinning species, Ep - endophagous species living under the bark, Fl - free-living species feeding on needles. 


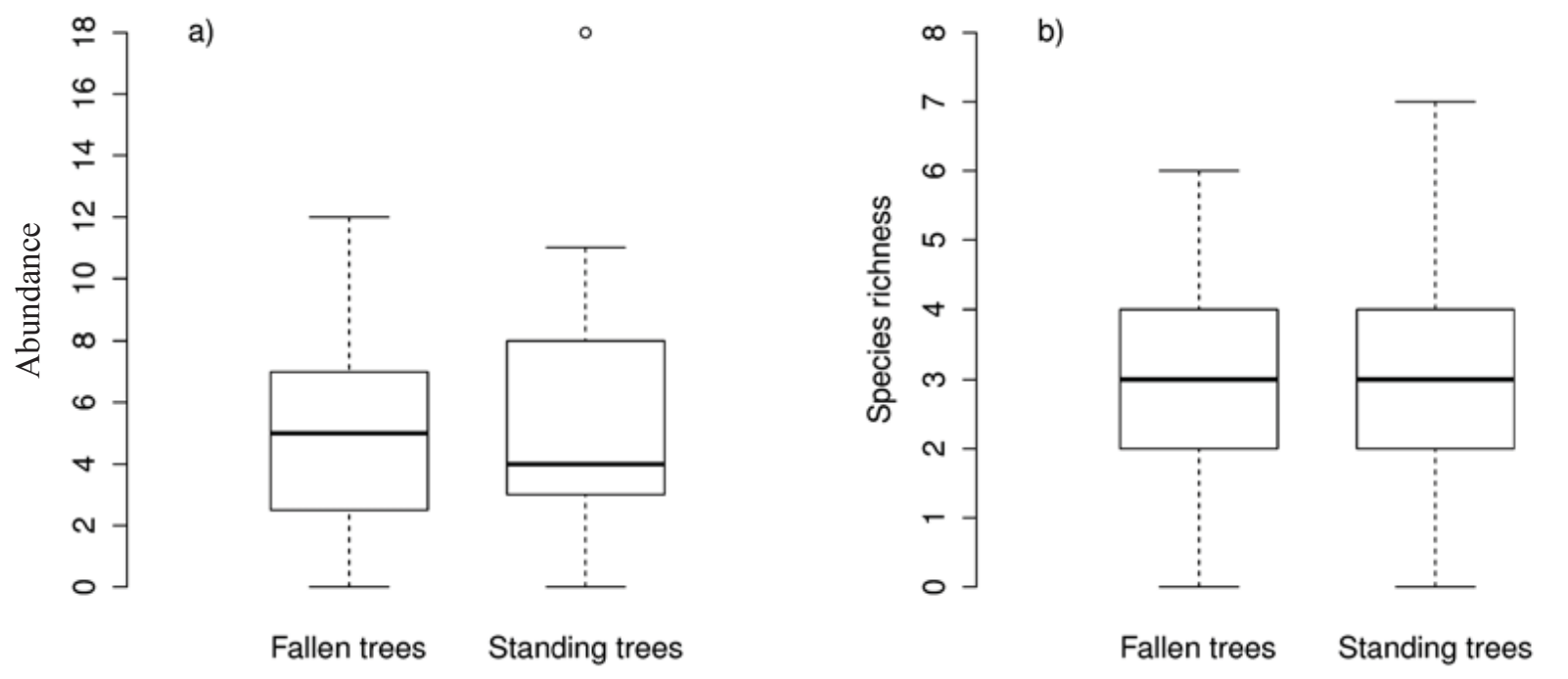

Figure 1 Box-plots displaying a) abundance and b) species richness of moth larvae on fallen and standing trees after wind storm. The High Tatras, spring 2013
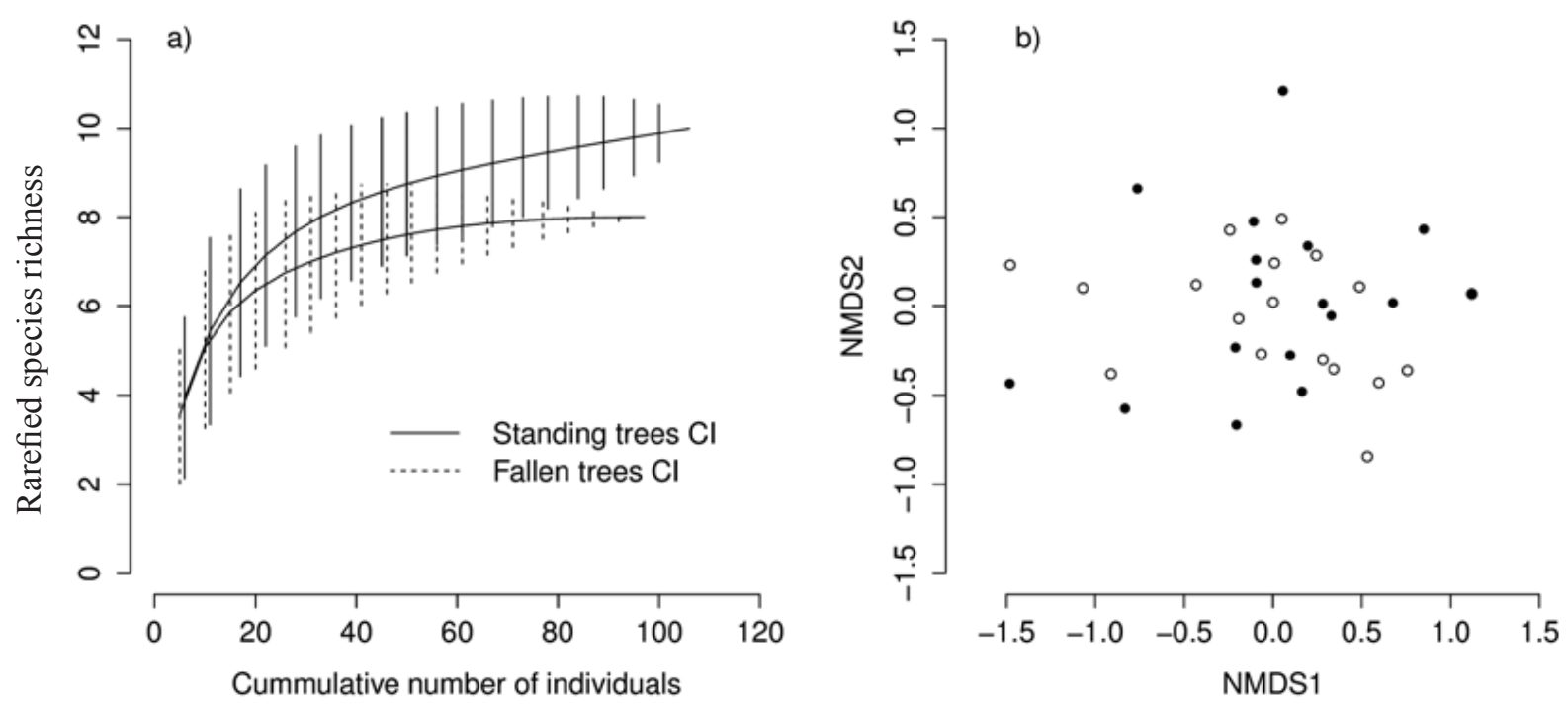

Figure 2 Comparison of moth larvae assemblages between fallen and standing spruce trees after the wind storm in the High Tatras in spring 2013. a) Rarefaction curves for species richness of moths on fallen and standing trees, CI - 95\% confidence interval. b) NMDS ordination graph; black points - moth assemblages of particular fallen trees, white points - moth assemblages of particular standing trees; the assemblages were compared using Bray-Curtis dissimilarity index (Bray \& Curtis 1957)

or by man - insect collectors (Hågvar 2007, Hirao et al. 2008, Kulfan et al. 2010, Meijer et al. 2012, etc.). Responses of tree-dwelling insects to wind-induced moving branches, twigs or leaves are poorly understood (Hågvar 2007,
Yamazaki 2011). Our results indicate that despite severe shaking during the wind-felling the spruce moth larvae were able to withstand the tree fall caused by wind storm. Whereas natural enemies and insect collecting cause 
shaking or moving branches suddenly, wind increases gradually, usually over a relatively long period of time. Hence, insects can adapt their behaviour, attaching tightly themselves to leaves or twigs. Some caterpillars can drop toward the ground and become suspended from the tree branch by a silk thread. They are able to regain their original position by climbing back up the silk lines (Sugiura \& Yamazaki 2006). However, the small-sized larvae which do not use silk lifeline have low chance for recolonisation of fallen tree because of their limited locomotion.

Based on the results, abundance of moth larvae and species richness of moth assemblages on fallen and standing trees were similar. This indicates the successful development of moth larvae on the fallen trees which is also likely when considering previous results (Kulfan \& Zach 2011). Newly emerged females do not lay their eggs on dead or dying fallen trees but on standing (living) trees nearby. This is why population density of particular moth species is expected to increase on trees which survived wind disturbance. There are numerous factors affecting density of forest moths (cf. e.g. Wallner 1987, Dajoz 2000, Ciesla 2011). However, it has not yet been mentioned that wind might be another factor influencing densities of moths on standing trees surviving wind disturbance.

The results show that moth larvae occurred in low abundance in the study area; therefore, highly likely, they could not cause serious damage to spruce forests. Low abundance of spruce moths is usual in the forests of West Carpathians (Kulfan \& Patočka 1997, Kulfan \& Zach 2004, Kulfan et al. 2010). However, some moth species occur as pests of spruce forests more or less frequently across Europe (Schwenke 1978). If larvae of such pests occur in high density before a wind storm, it is supposed that high proportion of them will remain on fallen trees able to complete their development there. Consequently, next generations of moth species coming from fallen trees could infest standing trees surviving wind disturbance. To confirm this, further research is needed.

\section{Acknowledgements}

The authors thank H. E. Roy for comments to earlier version of the manuscript and for linguistic corrections. M. Jurík, M. Mikuš and P. Tuček assisted with field studies. S. Viglášová provided valuable comments on the manuscript. Research was supported by the Grant Agency for Science (projects VEGA 2/0157/11, VEGA 2/0035/13).

\section{References}

Anderson M.J., 2001. A new method for non-parametric multivariate analysis of variance. Austral Ecology 26: 32-46. Web: http://entocert.net/PDF/MUVE/6_NewMethod_MANOVA1_2.pdf.

Basset Y., Springate N.D., Aberlenc H.P., Delvare G., 1997. A review of methods for sampling arthropods in tree canopies. In: Stork N.E., Adis J., Didham R.K., (eds.), Canopy arthropods. Chapman \& Hall, London, pp. 27-52. URL: http://www.aberlentomo.fr/pdf_publis_hpa/1997-27-Review_methods_sampling_canopies.pdf.

Bouget C., Duelli P., 2004. The effects of windthrow on forest insect communities: a literature review. Biological Conservation 118: 281-299. DOI: 10.1016/ j.biocon.2003.09.009.

Bradley J.D., Tremewan W.G., Smith A., 1973. British Tortricoid Moths, Cochylidae and Tortricidae: Tortricinae. The Ray Society, London, 251 p.

Bray J.R., Curtis J.T., 1957. An ordination of upland forest communities of southern Wisconsin. Ecological Monographs 27: 325-349. DOI: 10.2307/1942268.

Ciesla W., 2011. Forest entomology. John Wiley \& Sons, Chichester, 496 p. DOI: 10.1002/9781444397895.

Dajoz R., 2000. Insects and forests: the role and diversity of insects in the forest environment. Intercept Ltd, London, $668 \mathrm{p}$.

Greeney H.F., Dyer L.A., Smilanich A.M., 2012. Feeding by lepidopteran larvae is dangerous: A review of caterpillars' chemical, physiological, morphological, and behavioral defenses against natural enemies. Invertebrate Survival Journal 9: 7-34. URL: http://www.isj.unimo. it/articoli/ISJ256.pdf.

Hågvar S., 2007. Why do some Psylloidea and Heteroptera occur regularly on snow? Norwegian Journal of Entomology 54: 3-9. URL: http://www.entomologi.no/ journals/nje/2007-1/pdf/NJE-54-haagvar.pdf.

Hirao T., Murakami M., Iwamoto J., Takafumi H., Oguma H., 2008. Scale-dependent effects of windthrow disturbance on forest arthropod communities. Ecological Research 23: 189-196. DOI: 10.1007/s11284-007-0370-3. Hothorn T., Hornik K., Van de Wiel M., Zeileis A., 2013. 
COIN: conditional inference procedures in a permutation test framework. http://cran.r-project.org/web/packages/coin/index.html.

Faith D.P., Minchin P.R., Belbin L., 1987. Compositional dissimilarity as a robust measure of ecological distance. Vegetatio 69: 57-68. DOI: 10.1007/BF00038687.

Greenberg C.H., McNab W.H., 1998. Forest disturbance in hurricane-related downbursts in the Appalachian mountains of North Carolina. Forest Ecology and Management 104: 179-191. DOI: 10.1016/S03781127(97)00246-6.

Hollander M., Wolfe D.A., Chicken E., 2013. Nonparametric statistical methods (3rd edition). John Wiley \& Sons, New Jersey, 848 p.

Kruskal J.B., 1964. Multidimensional scaling by optimizing goodness of fit to a nonmetric hypothesis. Psychometrika 29: 1-27. DOI: 10.1007/ BF02289565.

Kruskal J.B., Wish M., 1978. Multidimensional scaling. Sage Publications, California, 96 p.

Kulfan J., Patočka J., 1997: Über die Fichten-Silbermotten (Lepidoptera, Yponomeutidae, Argyresthiinae) in den Westkarpaten. [Argyresthia moths (Lepidoptera, Yponomeutidae, Argyresthiinae) on Norway spruce in the West Carpathians] Anzeiger für Schädlingskunde, Pflanzenschutz, Umweltschutz, 70: 92-96. DOI: 10.1007/BF02009840.

Kulfan J., Zach P., 2004: Spoločenstvá motýl'ov na smreku obyčajnom (Picea abies) pozdĺž vertikálneho gradientu v Skalnatej doline. [Lepidopteran assemblages on Norway spruce (Picea abies) along an altitudinal gradient in the Skalnatá dolina valley] Štúdie o TANAP-e, 40: 311-319.

Kulfan J., Zach P., 2011. Successful overwintering of Lepidoptera larvae and eggs on spruce trees uprooted by the wind. Folia Oecologica 38: 52-56. URL: http://www. scopus.com/record/display.url?eid=2-s2.0-8335516928 5 \&origin $=$ inward\&txGid $=6$ CD8B1891F5B4E486C7C B077AB5DEE97.y7ESLndDIsN8cE7qwvy6w\%3a31.

Kulfan J., Kula E., Zach P., Dvoř́ácková K., Patočka J., Kršiak B., 2010. Caterpillar assemblages on introduced blue spruce: differences from native Norway spruce. Allgemeine Forst und Jagdzeitung 181: 188-194. URL: http://rheinischesmuseumfuerphilologie.de/fileadmin/ content/dokument/archiv/afjz/181_2010/Heft5/_03 Kulfan_6128.pdf.

Leather S.R., 2005. Insect sampling in forest ecosystems. Blackwell Science Ltd, Oxford, 303 p. DOI: 10.1002/9780470750513.

McArdle B.H., Anderson M.J., 2001. Fitting multivariate models to community data: a comment on distance-based redundancy analysis. Ecology 82: 290-297. DOI:10.1890/0012-9658(2001)082[0290: FMMTCD]2.0.CO;2.

Meijer K., Smit C., Beukeboom L.W., Schilthuizen M., 2012. Native insects on non-native plants in The Netherlands: curiosities or common practice? Entomologische Berichten 72: 288-293. URL: http://www.nev.nl/pages/ publicaties/eb/nummers/2012/72-6/288-293.pdf.
Mitchell S.J., 2013. Wind as a natural disturbance agent in forests: a synthesis. Forestry 86: 147-157. DOI: 10.1093/forestry/ cps058.

Nagel T.A., Svoboda M., Diaci J., 2006. Regeneration patterns after intermediate wind disturbance in an oldgrowth Fagus - Abies forest in southeastern Slovenia. Forest Ecology and Management 226: 268-278. DOI: 10.1016/j.foreco.2006.01.039.

Oksanen J., 2011. Vegan: ecological diversity. URL: http://cran.r-project.org/web/packages/vegan/vignettes/ diversity-vegan.pdf.

Oksanen J., 2013. Multivariate Analysis of Ecological Communities in R: vegan tutorial. URL http://cc.oulu. fi/ jarioksa/opetus/metodi/vegantutor.pdf.

Oksanen J., Blanchet F.G., Kindt R., Legendre P., Minchin P.R., O'Hara R.B., Simpson G.L., Solymos P., Stevens M.H.H., Wagner H., 2013. The vegan package. Community ecology package. URL: http://cran.r-project. org/web/packages/vegan/index.html.

Porter J., 1997. The color identification guide to caterpillars of the British Isles. Penguin Books, London, 275 p.

RDC Team, 2013. R: A language and environment for statistical computing. Vienna: R Foundation for Statistical Computing. URL: http://www.R-project.org.

Schelhaas M.J., Nabuurs G.J., Schuck A., 2003. Natural disturbances in the European forests in the $19^{\text {th }}$ and $20^{\text {th }}$ centuries. Global Change Biology 9: 1620-1633. DOI: 10.1046/j.1365-2486.2003.00684.x.

Schwenke W., 1978. Die Forstschädlinge Europas. Schmetterlinge. [The forest pests of Europe. Lepidoptera] Paul Parey, Hamburg, Berlin, 467 p.

Snodgrass G., 1993. Estimating absolute density of nymphs of Lygus lineolaris (Heteroptera: Miridae) in cotton using drop cloth and sweep-net sampling methods. Journal of Economic Entomology 86: 1116-1123. URL: http://www.ingentaconnect.com/content/esa/jee/ 1993/00000086/00000004/art00021.

Sugiura S., Yamazaki K., 2006. The role of silk threads as lifelines for caterpillars: pattern and significance of lifeline-climbing behaviour. Ecological Entomology 31: 52-57. DOI: 10.1111/j.0307-6946.2006.00755.x.

Wallner W.E., 1987. Factors affecting insect population dynamics: differences between outbreak and non-outbreak species. Annual Review of Entomology 32: 317 340. DOI: 10.1146/annurev. en.32.010187.001533.

Wilson J.M., Barclay R.M.R., 2006. Consumption of Caterpillars by Bats during an Outbreak of Western Spruce Budworm. American Midland Naturalist 155: 244-249. DOI: 10.1674/0003-0031(2006)155[0244: COCBBD]2.0.CO;2.

Yamazaki K., 2011. Gone with the wind: trembling leaves may deter herbivory. Biological Journal of the Linnean Society 104: 738-747. DOI: 10.1111/j.10958312.2011.01776.x.

Zhu J.J., Liu Z.G, Li X.F, Takeshi M., Yutaka G., 2004. Review: effects of wind on trees. Journal of Forestry Research 15: 153-160. DOI: 10.1007/BF02856753. 